\title{
Cystic Solitary Fibrous Tumor of the Liver: A Case Report
}

\author{
Karaciğerin Kistik Soliter Fibröz Tümörü: Olgu Sunumu

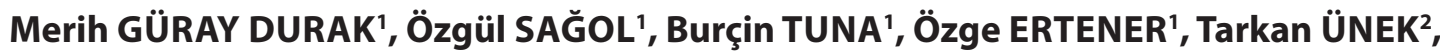 Sedat KARADEMIR ${ }^{2}$, Oğuz DiCLE ${ }^{3}$

Department of ${ }^{1}$ Pathology, ${ }^{2}$ General Surgery, ${ }^{3}$ Radiology, Dokuz Eylül University Faculty of Medicine, IZMiR, TURKEY

\begin{abstract}
Solitary fibrous tumors are unusual neoplasms that are rarely found in the liver parenchyma. They are usually described as hard, grayish white, well-defined lesions. Predominant cystic change in a solitary fibrous tumor is an unexpected finding, with only a few previous cases reported in the literature, two of which are localized in the head and neck region. Herein, we report a unique case of solitary fibrous tumor of the liver in a 38-year-old female with predominant multiloculated cystic appearance, and discuss the histopathologic differential diagnosis.
\end{abstract}

Key Words: Solitary fibrous tumor, Liver, Cysts

\section{ÖZ}

Soliter fibröz tümörler, karaciğer parenkiminde de ender olarak bildirilen sıradışı neoplazmlardır. Genel olarak sert, gri-beyaz renkli, iyi sınırlı lezyonlar olarak tanımlanırlar. Soliter fibröz tümörler içerisinde belirgin kistik değişiklik bulunması pek beklenen bir bulgu değildir. Literatürde kistik değişiklik gösteren birkaç soliter fibröz tümör olgusu bildirilmiș olup, bunlardan ikisi baș boyun bölgesinde lokalizedir. Burada, 38 yaşında kadın hastada, karaciğerde yerleşim gösteren ve baskın olarak multiloküle kistik görünüm içeren bir soliter fibröz tümör olgusu, histopatolojik ayırıcı tanı özellikleri ile birlikte sunulmuştur.

Anahtar Sözcükler: Soliter fibröz tümör, Karaciğer, Kistler

\section{INTRODUCTION}

Solitary fibrous tumors are rare neoplasms found primarily in the pleura, but also in almost every anatomic location including serosal cavities, upper respiratory tract, retroperitoneum, abdominal cavity, oral cavity, and meninges. They are also very rare in the liver parenchyma, with fewer than 45 previous cases reported up to date in the world literature $(1,2)$. Grossly, solitary fibrous tumors are firm, greyish white, well-demarcated lesions. Although the histogenesis of these tumors is controversial, mesenchymal origin is preferred other than mesothelial origin. The major histologic finding of solitary fibrous tumors is proliferation of spindle cells in various patterns that are accompanied by various degrees of collagenous deposition. Rarely cystic changes may occur in these tumors but only a few cases with both radiologic and macroscopic multiloculated cystic appearance have been reported in the literature, two of which are localized in the head and neck region (3-5). To the best of our knowledge, predominant cystic change in a solitary fibrous tumor has not been described in the liver. Herein, we present a unique case of solitary fibrous tumor of the liver with prominent macroscopic multiloculated cystic appearance.

(Turk Patoloji Derg 2013, 29:217-220)

Received : 30.03.2011 Accepted : 20.04.2011

\section{CASE REPORT}

A 38-year-old female presented at the Emergency Department of our hospital with symptoms of abdominal pain, nausea and vomiting. Physical examination of the patient did not reveal significant pathology. Abdominal computed tomography demonstrated a well-demarcated multilocular cystic mass with a few mural nodules, located at the lower edge of segment $4 \mathrm{~b}$ of the liver that seemed to have connection with the liver (Figure 1). The mass was excised laparoscopically.

On gross examination, the excised specimen consisted of a multilocular cystic lesion that measured $8 \times 6 \times 2 \mathrm{~cm}$ (Figure 2). Serous fluid was emptied from the intact cystic spaces within the lesion. Although the integrity of the lesion could not be preserved due to the surgical procedure, a small fragment of liver parenchyma was apparent adjacent to the lesion at the periphery of the specimen.

Histopathologic examination showed a highly vascular lesion, and some of the vessels had typical stag horn configuration. Focal areas of the lesion had densely packed immature appearing fibroblast-like spindle cells with sparse

Correspondence: Merih GÜRAY DURAK

Dokuz Eylül Üniversitesi Tip Fakültesi, Patoloji Anabilim Dalı,

IZMIR, TURKEY

E-mail: merih.guray@deu.edu.tr Phone: +90 2324123419 


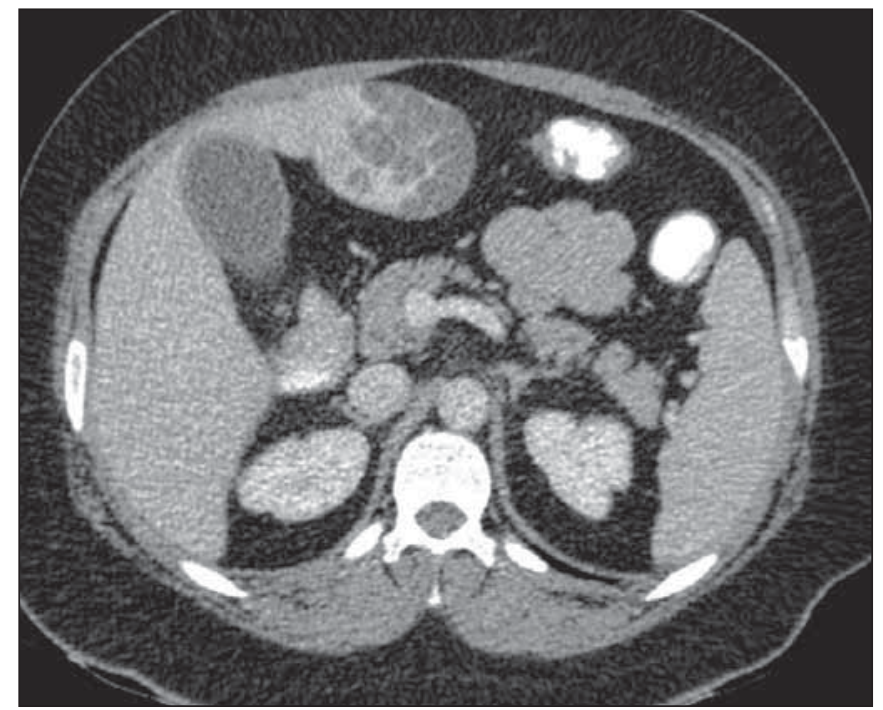

Figure 1: Abdominal computed tomography reveals a multiloculated, well-circumscribed cystic lesion, extending from the liver parenchyma towards mesenteric cavity in an exophytic fashion.

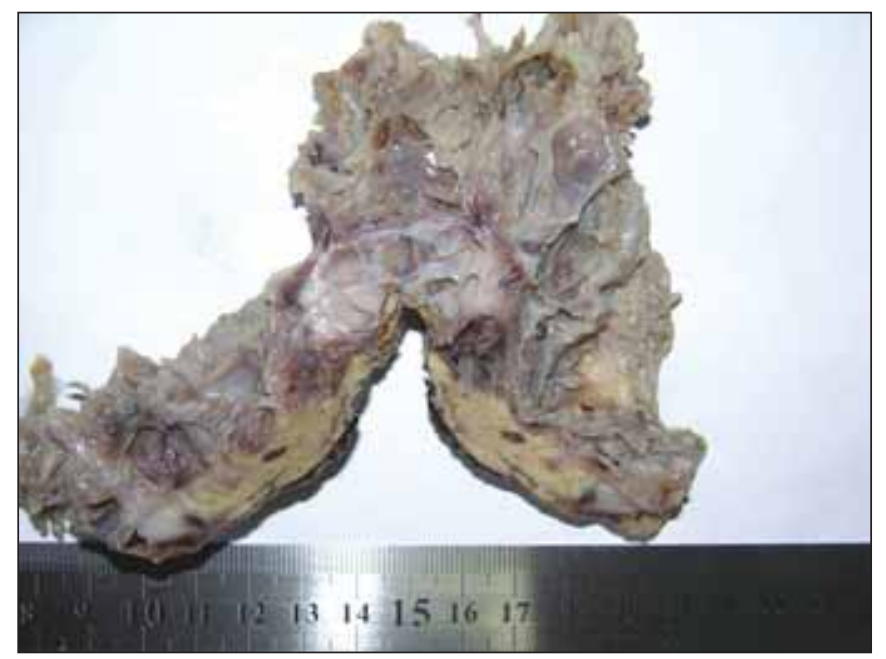

Figure 2: Grossly, the tumor has prominent multiloculated cystic appearance.

cytoplasm and uniform, elongated nuclei reminiscent of ovarian-type stroma (Figure 3A). There was no mitotic activity, nuclear pleomorphism or necrosis in the tumor. In some areas, perivascular hyalinization and myxoid degeneration was prominent. Cystic spaces showed no epithelial lining in the majority of the lesion (Figure 3B). However, when the specimen was sampled totally for the sake of completeness, endothelial cells lining the cysts were seen in only focal areas (Figure 3C). Immunohistochemical analysis revealed diffuse strong positivity for CD 34 (Figure 4A), CD 99, smooth muscle actin, and focal weak positivity for estrogen and progesterone receptors in spindle cells
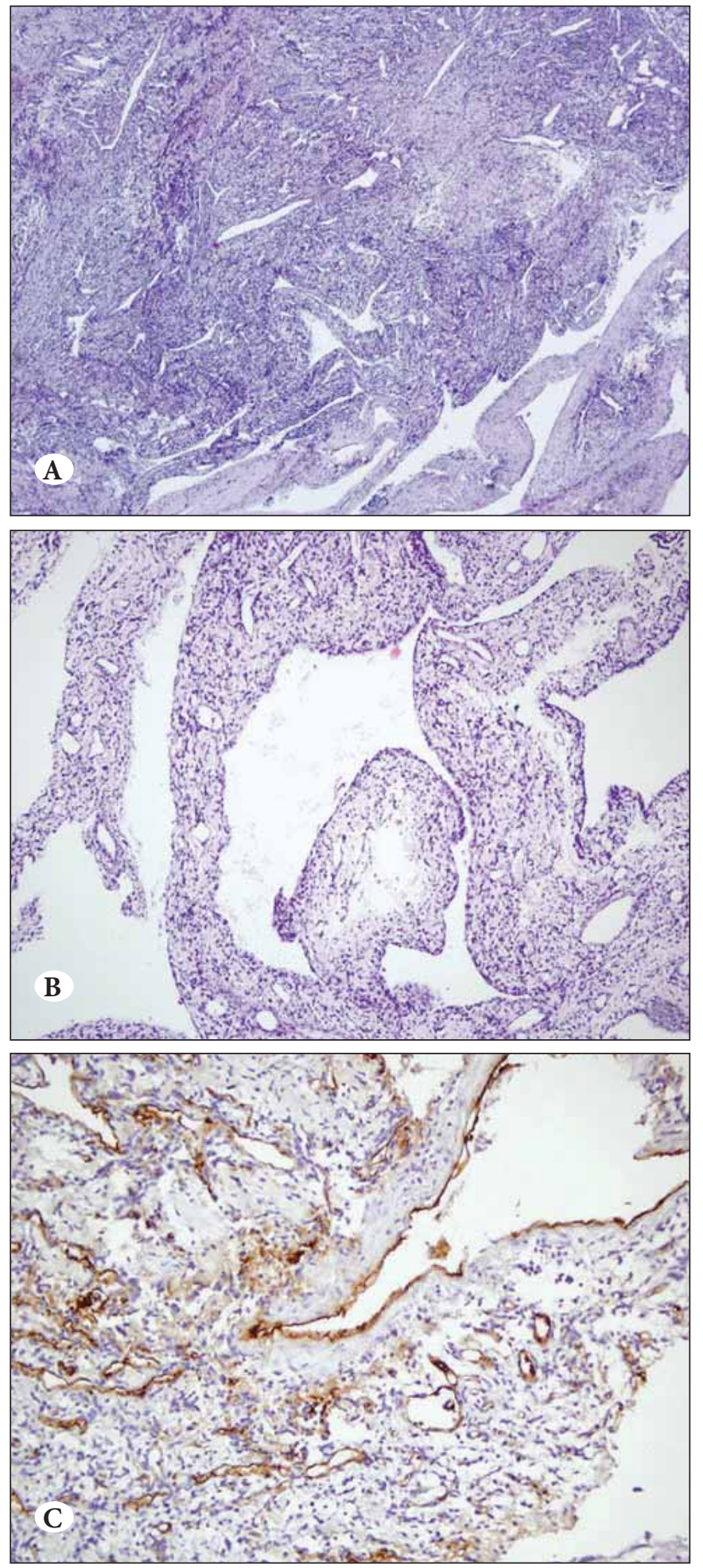

Figure 3: (A) Microscopically, dense spindle-cell proliferation reminiscent of ovarian-type stroma is seen between vascular structures that have staghorn appearance ( $\mathrm{H} \& \mathrm{E}, \mathrm{x} 40)$, (B)The majority of the lesion consists of cystic spaces with no lining epithelium (H\&E, x100), (C) However, endothelial cells lining cystic spaces, that stain positively with factor-VIII immunohistochemical staining can be seen in focal areas (x100). 

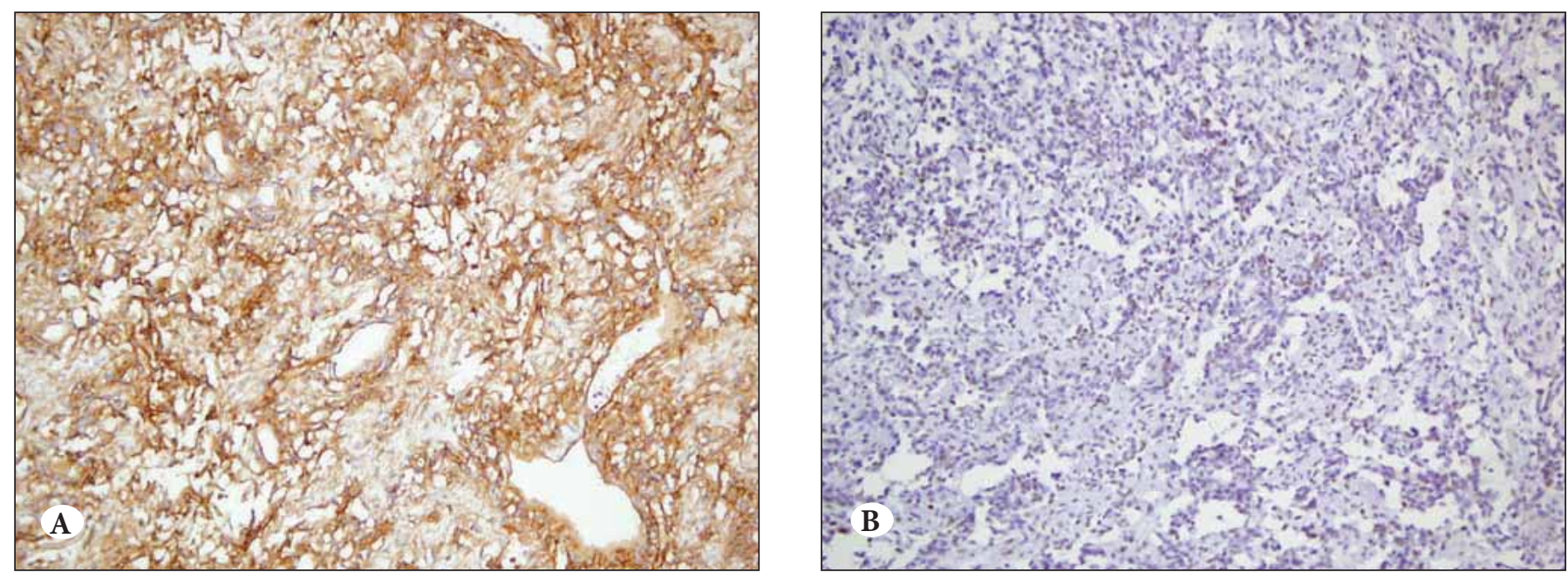

Figure 4: (A) Immunohistochemically, neoplastic cells show diffuse positivity with CD34 (x100), (B) and focal nuclear positivity with estrogen receptor (x100).

(Figure 4B). The neoplastic cells were negative for CD 31, factor VIII, S-100, cytokeratin 7, epithelial membrane antigen, CD 117, inhibin, calretinin, and melan-A. The Ki-67 proliferation index of the tumor was between 5\% and $10 \%$. On the basis of the morphologic features and immunohistochemical staining results, the patient was diagnosed as solitary fibrous tumor of the liver.

\section{DISCUSSION}

Solitary fibrous tumors of the liver are uncommon neoplasms, with less than 45 previous cases reported in the world literature $(1,2)$. According to these reported cases, the tumors are more frequent in females with a mean age of 50 years. Clinical features include abdominal discomfort and mass, vomiting, fatigue, weight loss, and in some cases signs of hypoglycemia $(1,2,6-8)$. Most of the tumors arise from the left lobe of the liver and become fairly large, reaching sizes as large as $32 \mathrm{~cm}(1,9)$. The choice of treatment is complete surgical resection in the vast majority of cases. Among the limited number of cases reported in the literature, two patients have been shown to behave in a malignant fashion $(9,10)$.

Our patient was a young adult female with primary symptoms of abdominal pain and discomfort. When the age of the patient, the macroscopic multiloculated cystic appearance of the tumor, and spindle cell proliferation resembling ovarian-like stroma were considered together, mucinous cystic neoplasm of the liver was the main differential diagnosis. The mucinous cystic tumor is a neoplasm composed of cystic spaces lined by mucinproducing epithelial cells with an associated dense stroma similar to ovarian stroma. Because the epithelium of mucinous cystic neoplasms may often be denuded, it is advised that numerous histologic sections should be sampled in order to demonstrate the epithelial lining. In our case, although the specimen was sampled totally, no epithelial lining within cystic spaces was seen. Only focally, factor-VIII positive endothelial cells lined the cystic spaces, which led us to interpret these cystic spaces as ectatic vascular channels.

Ovarian-type stroma is defined as densely packed spindleshaped cells with round to oval nuclei and sparse cytoplasm, with a dense layer of collagenous connective tissue. This type of stroma has been described in a number of neoplasms, including mucinous cystic neoplasms of the pancreas, liver, retroperitoneum and ovary, and pancreatic lymphangiomas (11-13). Recent studies have demonstrated that the presence of ovarian-type stroma is required for the diagnosis of mucinous cystic neoplasms $(11,12,14)$. Nevertheless, it is important to be able to differentiate ovarian-type stroma from nonspecific hyalinized collagenous stroma.

The ovarian-type stromal cells have been reported to be labelled with antibodies to vimentin, smooth-muscle actin, desmin (focally), calretinin, alpha-inhibin (15), melan-A, CD 99, and bcl 2. It is also well known that estrogen and progesterone receptors are expressed in the ovarian-type stroma of mucinous cystic neoplasms in $25 \%$ and 50$75 \%$ of cases, respectively (16). This immunophenotype of ovarian-type stroma is very similar to that of normal ovarian stroma, and therefore supports its similarity to true ovarian stromal tissue. The neoplastic cells of our case did not stain for inhibin, calretinin, or melan-A. However, there was focal weak staining for both estrogen and progesterone receptors. Nevertheless, these hormone receptors have 
been shown to be expressed in a wide range of tissues and tumors, including a few cases of solitary fibrous tumor (17).

In our case, spindle cell neoplasms of the liver was also in the differential diagnosis because of dense cellular areas with spindle cell proliferation, in between the ectatic vascular spaces. Immunohistochemical staining profile of the tumor, that included CD 34, CD 99 and smooth muscle actin positivity, as well as negative staining for cytokeratin, epithelial membrane antigen, CD 117 and S-100, together with the morphologic findings, was highly suggestive for the diagnosis of solitary fibrous tumor.

It is difficult to establish the biologic behavior of solitary fibrous tumors of the liver because of the limited number of cases reported in the literature. Complete surgical resection of the tumor with adequate safe margins and close followup of the patient seem to be the mainstay of treatment (8). Features associated with malignancy in both thoracic and extrathoracic solitary fibrous tumors have been reported as increased cellularity, pleomorphism, $>4$ mitotic figures per 10 high power fields, presence of necrosis/hemorrhage, large size of the tumor $(>10 \mathrm{~cm})$, and atypical location of the tumor such as parietal pleura (18). Our patient is free of any evidence of local recurrence or metastatic disease 12 months post operation. However, because of the size of the tumor $(8 \times 6 \mathrm{~cm})$, high cellularity in focal areas and relatively high Ki-67 proliferation index, close follow-up of the patient is necessary.

In conclusion, solitary fibrous tumors of the liver are rare lesions. Cystic changes may rarely occur in these tumors. In presence of a predominantly multiloculated cystic appearance in a tumor located in the liver, mucinous cystic neoplasms and solitary fibrous tumors should also be considered in differential diagnosis.

\section{REFERENCES}

1. Perini MV, Herman P, D'Albuquerque LA, Saad WA: Solitary fibrous tumor of the liver: Report of a rare case and review of the literature. Int J Surg 2008, 6:396-399

2. Fama F, Le Bouc Y, Barrande G, Villeneuve A, Berry MG, Pidoto $R R$, Saint Marc O: Solitary fibrous tumour of the liver with IGFII-related hypoglycaemia. A case report. Langenbecks Arch Surg 2008, 393:611-616

3. Clarençon F, Bonneville F, Chiras J, Kujas M, Cornu P: Cystic intraventricular solitary fibrous tumor. AJNR Am J Neuroradiol 2007, 28:1205-1206

4. Wat SY, Sur M, Dhamanaskar K: Solitary fibrous tumor (SFT) of the pelvis. Clin Imaging 2008, 32:152-156
5. Turkoglu E, Dolgun H, Kazancı B, Yilmaz ER, Kahveci R, Sekerci Z: Solitary fibrous tumour of the ethmoid sinuses and anterior fossa. BMJ Case Rep 2009, bcr04.2009.1767

6. Ji Y, Fan J, Xu Y, Zhou J, Zeng HY, Tan YS: Solitary fibrous tumor of the liver. Hepatobiliary Pancreat Dis Int 2006, 5:151-153

7. Nath DS, Rutzick AD, Sielaff TD: Solitary fibrous tumor of the liver. AJR Am J Roentgenol 2006, 187:W187-190

8. Korkolis DP, Apostolaki K, Aggeli C, Plataniotis G, Gontikakis E, Volanaki D, Sebastiadou M, Dimitroulopoulos D, Xinopoulos D, Zografos GN, Vassilopoulos PP: Solitary fibrous tumor of the liver expressing CD34 and vimentin: A case report. World J Gastroenterol 2008, 14:6261-6264

9. Yilmaz S, Kirimlioglu V, Ertas E, Hilmioglu F, Yildirim B, Katz D, Mizrak B: Giant solitary fibrous tumor of the liver with metastasis to the skeletal system successfully treated with trisegmentectomy. Dig Dis Sci 2000, 45:168-174

10. Chan G, Horton PJ, Thyssen S, Lamarche M, Nahal A, Hill DJ, Marliss EB, Metrakos P: Malignant transformation of a solitary fibrous tumor of the liver and intractable hypoglycemia. J Hepatobiliary Pancreat Surg 2007, 14:595-599

11. Lam MM, Swanson PE, Upton MP, Yeh MM: Ovarian-type stroma in hepatobiliary cystadenomas and pancreatic mucinous cystic neoplasms. Am J Clin Pathol 2008, 129:211-218

12. Goh BKP, Tan YM, Chung YFA, Chow PKH, Cheow PC, Wong WK, Ooi LLPJ: A review of mucinous cystic neoplasms of the pancreas defined by ovarian-type stroma: Clinicopathological features of 344 patients. World J Surg 2006, 30:2236-2245

13. Adsay NV: Cystic neoplasia of the pancreas: pathology and biology. J Gastrointest Surg 2008, 12:401-404

14. Murakami Y, Uemura K, Morifuji M, Hayashidani Y, Sudo T, Sueda T: Mucinous cystic neoplasm of the pancreas with ovariantype stroma arising in the head of the pancreas: Case report and review of the lierature. Dig Dis Sci 2006, 51:629-632

15. Yeh MM, Tang LH, Wang S, Robert ME, Zheng W, Jain D: Inhibin expression in ovarian-type stroma in mucinous cystic neoplasms of the pancreas. Appl Immunohistochem Mol Morphol 2004, $12: 148-152$

16. Hruban RH, Pitman MB, Klimstra DS: Mucinous cystic neoplasms. In Silverberg SG. (Ed): AFIP Atlas of Tumor Pathology Series 4. Tumors of the Pancreas. Washington DC, 2007, 51-74

17. Piperi E, Rohrer MD, Pambuccian SE, Koutlas IG: Vascular solitary fibrous tumor with "floret" cells or giant cell angiofibroma? A lingual example highlighting the overlapping characteristics of these entities and positive immunoreaction for estrogen and progesterone receptors. Oral Surg Oral Med Oral Pathol Oral Radiol Endod 2009, 107:685-690

18. Weiss SW, Goldblum JR: Soft tissue tumors of intermediate malignancy of uncertain type. In Weiss SW, Goldblum JR. (Eds): Enzinger and Weiss's Soft Tissue Tumors. 5th ed., Philadelphia, Mosby Elsevier, 2008, 1129-1134 